I wish to thank Dr W. F. J. Cuthbertson of Glaxo Laboratories Ltd and $\mathrm{Mr}$ F. A. Todd of Genatosan Ltd for information about the preparation of the caseins used in the experiments described in this paper. Mr Todd made the preparations of alcohol-ether extracted caseins from skim milks of different origins.

\title{
REFERENCES
}

Abell, M. R. \& Beveridge, J. M. R. (1949). Canad. F. Res. 27, sect. E, p. $3^{16 .}$

Abell, M. R. \& Beveridge, J. M. R. (195I). Arch. Path. 52, 428.

Dam, H. (1953). Experientia, Suppl. I, p. I95.

Gillman, J., Gilbert, C., Gillman, T. \& Spence, I. (1952). Amer. F. dig. Dis. 19, 201.

Goettsch, M. (1948). Arch. Biochem. 19, 349.

Goettsch, M. (1949). Arch. Biochem. 21, 289.

Goettsch, M. (1951). F. Nutr. 44, 443.

György, P. \& Goldblatt, H. (1939). Ұ. exp. Med. 70, I 85 .

György, P. \& Goldblatt, H. (I949). F. exp. Med. 89, 245.

György, P. \& Goldblatt, H. (I95 I). Proc. Soc. exp. Biol., N.Y., 76, г24.

György, P., Rose, C. S., Tomarelli, R. M. \& Goldblatt, H. (1950). F. Nutr. 4I, 265.

Himsworth, H. P. \& Glynn, L. E. (1944-5). Clin. Sci. 5, 93.

Himsworth, H. P. \& Lindan, O. (1 949). Nature, Lond., 163, 30.

Hock, A. \& Fink, H. (1943). Hoppe-Seyl. Z. 278, 136.

Hove, E. L., Copeland, D. H. \& Salmon, W. D. (1949). F. Nutr. 39, 397.

Lindan, O. (I95I). Brit. F. exp. Path. 32, 47 I.

Lindan, O. \& Himsworth, H. P. (1950). Brit. F. exp. Path. 31, 65 I.

Lindan, O. \& Work, E. (I95Ia). Biochem. F. 48, 337.

Lindan, O. \& Work, E. (195. Ib). Biochem. F. 48, 344 .

McLean, J. R. \& Beveridge, J. M. R. (1952). F. Nutr. 47, 4I.

Naftalin, J. M. (195I). F. Path. Bact. 63,649.

Naftalin, J. M. (1952). Lancet, $\mathbf{2 6 3}$, ror 3 .

Naftalin, J. M. (1954a). Ann. N.Y. Acad. Sci. 57, 862.

Naftalin, J. M. (1954b). Ann. N.Y. Acad. Sci. 57, 869.

Naftalin, J. M. (1954c). F. Path. Bact. 67, 335.

Schwarz, K. (1944). Hoppe-Seyl. Z. 281, 101.

Schwarz, K. (1948). Hoppe-Seyl. Z. 283, i86.

Schwarz, K. (195I). Proc. Soc. exp. Biol., N.Y., 78, 852.

Schwarz, K. (1952). Proc. Soc. exp. Biol., N.Y., 80, 3 I 9.

Sherman, H. C. \& Merrill, A. T. (1925). F. biol. Chem. 63, 33 I.

Wahi, P. N. (1949). Arch. Path. 47, i 19.

Weichselbaum, T. E. (1935). Quart. F. exp. Physiol. 25, 363.

\section{Storage of Vitamins in Liver}

\section{By E. KodICEK, Dunn Nutritional Laboratory, University of Cambridge and Medical Research Council}

I propose to describe as storage that amount of vitamin laid down in excess of the actual physiological level needed for normal functioning of the organ. When using this criterion it can be seen that the vitamins fall roughly into three groups. (I) Those that are used by the tissues to be built into coenzyme systems and are precursors of prosthetic groups of enzymes. I shall call them prosthetins. Their level in the liver does not appear to exceed a certain saturation point, which most likely is the saturation of apoenzymes by their respective prosthetic groupings. 
(2) The second group contains the vitamins of the fat-soluble group, which behave differently in that their concentration in liver tissue can be increased enormously by dosing. It is likely that this and other differences, which there is no space to enumerate, are due to a mode of action different from that of the water-soluble group. (3) The third group contains vitamins whose exact biochemical function is not yet known.

\section{Prosthetins}

Table I summarizes the approximate content in livers of various mammals. It can be seen that there is little difference between the various species in the concentration of a particular vitamin. It may be pointed out that biotin, whose function

\section{Table 1. Approximate prosthetin* content of the livers of various mammals $(\mu g / g)$}

\begin{tabular}{|c|c|c|c|c|c|c|c|}
\hline Animal & Nicotinamide & Riboflavin & Thiamine & Pyridoxin & $\begin{array}{c}\text { Pantothenic } \\
\text { acid }\end{array}$ & Folic acid & Biotin \\
\hline $\mathrm{Ox}$ & $100-175$ & $20-37$ & $2-4$ & 7 & $42-76$ & 3 & $1 \cdot 2$ \\
\hline Calf & $120-165$ & $14-44$ & $1-5$ & 3 & $40-75$ & - & 0.8 \\
\hline Sheep & I30-I 50 & $29-50$ & $2-4$ & 4 & $53-70$ & 3 & $1 \cdot 3$ \\
\hline Pig & $\times 30-190$ & $25-44$ & $2-5$ & $3-10$ & $35-68$ & 2 & 0.8 \\
\hline Chick & I 52 & 22 & - & — & - & $4^{-7}$ & - \\
\hline Rat & $100-180$ & 30 & 8 & 2 & $80-110$ & 3 & $I-I \cdot 5$ \\
\hline Man & 60 & I I -16 & 2 & 3 & 40 & 7 & 0.7 \\
\hline
\end{tabular}

in a coenzyme system has not yet been fully established, nevertheless has a fair concentration in liver tissue in comparison to the extremely small requirements which are about a thousandth of that of thiamine. This may indicate an intensive turnover in the liver and a high degree of utilization. These levels are characteristic of particular vitamins and are not greatly exceeded under any circumstances. In deficiency, the level of the vitamin decreases to about half its value, rarely to a lower level, never to zero. Since almost all the B-vitamins are present in the liver in the form of their respective coenzymes (pyridine nucleotides, flavin nucleotides, thiamine pyrophosphate, lipothiamide pyrophosphate, coenzyme A and formyl cofactor), the coenzyme content decreases in deficiency. Certain enzymes depending on their prosthetic groups show a decreased activity (Snell, I953; Novelli, 1953; Reed, 1953; Lardy \& Peanasky, I953).

On administration of the vitamin, the content in the deficient livers returns to its former level and increasing doses of the vitamin will not raise it much higher. Characteristic examples can be found in the studies of Schultz, Light, Cracas \& Atkin (1939), who gave to rats graded doses of thiamine, and in those of Totter, Martindale, McKee, Keith \& Day (1949) who administered folic acid to chicks.

Similar findings could be quoted for the other vitamins of this group. The depletion and restoration of the vitamin content is influenced by factors related to the characteristic metabolic function of the vitamin. Thus, for instance, the level 
of protein, amount of tryptophan, the type of carbohydrate in the diet, the proportion of amino-acids, and other factors will influence the depletion of the nicotinic acid of the liver.

When large doses of a vitamin of this group are administered, the body tissues, and particularly the liver, react by mechanisms which destroy or detoxify the excess vitamin, which is then eliminated by the kidneys. Thus, for instance, when large doses of nicotinic acid are given, especially on an empty stomach, the liver cannot deal with the large amounts offered to it, and free nicotinic acid appears in the circulation and in the urine which under normal circumstances does not contain any nicotinic acid, but only nicotinylglycine, nicotinamide or its methylated derivatives. Dosing with nicotinic acid and following its fate in the urine has been suggested as a possible test of liver function (Reddi \& Kodicek, 1953).

Among the various factors that influence the B-vitamin content of the liver is the level of dietary protein, an increase in which affects beneficially the content of folic acid, biotin, pantothenic acid and riboflavin (Wright \& Skeggs, I946). The content of pyridoxin, however, is inversely related to the level of protein in the diet, possibly owing to the greater demand for the vitamin in the increased turnover of amino-acids.

\section{Fat-soluble vitamins}

In the group of the fat-soluble vitamins the question of true storage is of particular importance. On vitamin A especially a great mass of information has accumulated (see reviews by Goodwin, 1951; Moore, r953 $a-c$; Wald, 1953).

In general, it can be said that this group differs from the prosthetins in that the vitamin content of the liver can be, by external supplies of the vitamin, increased greatly (roo-fold or more) beyond the level found in animals subsisting on an ordinary diet.

\section{Vitamin $A$}

A number of factors contribute to the variations in liver content of vitamin A. Absorption. Vitamin A alcohol taken by mouth is esterified in the intestinal wall and passes as ester through the lymph into the blood where it causes a temporary rise in the ester fraction, above and beyond the vitamin A normally present there as the free alcohol. The vitamin is taken up by the liver and deposited as ester.

When esters of vitamin $A$ are fed, they appear to be de-esterified and re-esterified in the intestinal wall. When, however, a large amount of unnatural esters is administered, the same esters can be recovered in the liver (Gray, Hickman \& Brown, 1940). Smaller amounts fed over a longer period appear in the liver in the form of natural esters (Gray \& Cawley, 1942).

Carotene is converted in the intestinal wall of many animals into vitamin A, possibly via the vitamin $A$ aldehyde and eventually stored in the liver as vitamin $A$ (Glover, Goodwin \& Morton, 1948). There is still some doubt if this scheme applies to all mammals, whether, for instance, the cow or man which absorb carotene as 
such transform the provitamin elsewhere, possibly in the liver. Thus injection of carotene into the portal blood of dogs (Kowalewski \& Henrotin, 1950) caused an increase of vitamin $A$ in liver. The question of various isomers of carotene and their absorption and eventual storage as vitamin A has been studied extensively (Zechmeister, 1937). Recently Ganguly, Mehl \& Deuel $(1953 a, b)$ have investigated this matter and divide animals into four groups with regard to their ability to absorb carotenoids and to store them in the liver. They suggest that this question is related to the availability of certain protein acceptors.

When stereoisomers of vitamin A are fed, such as neovitamin A (Robeson \& Baxter, 1947), the 5-cis-isomer, or $\triangle_{3}$-cis-retinene (Graham, van Dorp \& Arens, 1949), the liver appears to store the dose partly in all-trans form (the natural form) indicating that the body can isomerize the various compounds (Harris, Ames \& Brinkman, 195I). This ability of tissues is of importance since it supports the suggestion of Wald (1953) that the isomerization of trans-vitamin A to an unknown cis-vitamin A, necessary for the reconstitution of rhodopsin, occurs somewhere in the body (liver ?) and not in the eye. Administration of vitamin A in colloidal water suspension results in higher vitamin reserves due to better absorption (Sobel, Sherman, Lichtblau, Snow \& Kramer, I948).

Liver. The liver like blood (Krause \& Alberghini, I950) contains a potent vitamin A esterase (McGugan \& Laughland, 1952; Ganguly \& Deuel, I953; Krause \& Powell, 1953) which is mainly contained in the microsomal fraction of liver homogenates. The vitamin A content of liver appears to be distributed between the Kupffer and parenchymatous cells (Popper, 194I). Vitamin A alcohol and ester appear to be bound to proteins, as in blood, possibly to different protein fractions (Krinsky \& Ganguly, 1953). The most usual form found in liver of mammals is vitamin $A_{1}$, though vitamin $A_{2}$ can be found when ingested by the animal.

Storage. A dose or doses of vitamin A alcohol or ester will cause a rise in liver vitamin $A$ and stores are built up far greater than the amounts normally encountered (Lemley, Brown, Bird \& Emmett, 1947; Davies \& Moore, 1948; Guerrant, 1949; Moore, Sharman \& Ward, 1951; Booth, 1952). It appears that the efficiency of storage increases until it reaches a maximum of about $80 \%$ and then declines when toxic levels are reached. The vitamin A aldehyde, retinene, is efficiently absorbed from the gut, subcutaneous tissue or peritoneum, and stored in the liver as vitamin A (Glover et al. r948). In contrast to this, vitamin A acid, a synthetic compound not yet found naturally, does not increase the liver stores (Arens \& van Dorp, 1946; Sharman, 1949). Carotene also increases the stores of vitamin A in the liver, but less efficiently than the preformed vitamin A (Davies \& Moore, 1934).

Sex. Another factor which influences the amount and rate of deposition and also the rate of depletion of vitamin A stores is the sex of animals. Moore et al. (I95 I) and Booth (1952) showed that female rats have larger reserves than male, other factors being constant. A reversed relation exists for the stores in kidneys. Recently High \& Day (195I) pointed out that the sex difference may, to a large 
extent at least, be related to the difference in rate of growth. The vitamin A content of the livers of male rats whose food intake was restricted so that they grew at the same rate as females was the same as that of the females. The results are in line with the findings of Johnson \& Baumann (I948a), who showed that restriction in the growth rate promoted the retention of vitamin $A$ in the liver.

Age. Mammals appear to be born with negligible reserves, owing to the lack of placental transfer of the vitamin. The reserves increase with the supply of milk, and especially of colostrum (Moore, I953a).

Other factors. Administration of tocopherols increases the vitamin A deposition in liver or slows down its depletion (Moore, I940; Davies \& Moore, 194I). Large amounts of tocopherol, however, have a reverse effect when given in conjunction with carotene (Johnson \& Baumann, I948b; High \& Day, I951 ; Swick \& Baumann, I952a).

Among other factors that affect the storage of vitamin A are certain types of liver damage, such as cirrhosis (Ralli, Papper, Paley \& Bauman, I94I; Meyer,

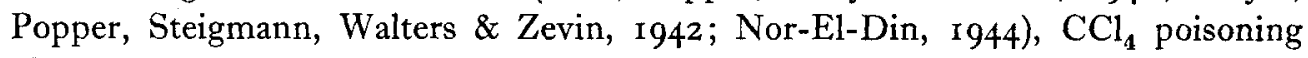
(Popper, Steigmann \& Dyniewicz, 1942), administration of certain carcinogens (Baumann, Foster \& Lavik, I94I; Baumann, Foster \& Moore, 1942), atabrine (Guggenheim, 1952), ethanol (Baumann et al. 1942; Moore, 1953a), succinylsulphathiazole, vitamin $B_{12}$ and penicillin (Kemmerer, Fraps \& DeMottier, I947; Burgess, Gluck, Brisson \& Laughland, I95I; Coates, Harrison, Kon, Porter \& Thompson, I952; High \& Wilson, 1953) and yeast (Braude, Henry, Kon \& Thompson, 1947). Aureomycin given to rats did not influence the liver stores of vitamin A (Hartsook, Batchelor \& Johnson, I953).

\section{Calciferol}

Until recently, very little could have been said about the storage of vitamin D. Greaves \& Schmidt $(1934 a, b)$ found that bile is important for efficient absorption of vitamin D. Jaundiced rats stored little vitamin in the liver, unless it was injected subcutaneously. Heymann (1937-8, 1938) found that rats with a ligated bile duct and suffering in consequence from an obstructive biliary cirrhosis of the liver, needed a ten to twelve times greater dose of vitamin $D$ than controls. It appeared that the normal functioning of liver was also essential since rats with a direct liver damage needed two to twelve times more vitamin D than controls. A small part of the dose of vitamin $\mathrm{D}$ appeared to be re-excreted in dogs through the bile.

Extremely small amounts of vitamin D are found in livers of various animals (Table 2) as compared to the large amounts found in fish livers.

There is some evidence of a seasonal variation in the liver vitamin D in cattle, which are reported to have a higher content in the late part of the pasture season (Eaton, Spielman, Loosli, Thomas, Norton \& Turk, 1947). There is some doubt if there is any placental transfer of vitamin $D$. The content of livers of newborn calves increased slightly, but inconsistently when the mothers received high doses of the vitamin (Eaton et al. 1947).

In recent years, we have studied by biological assay the distribution of vitamin 
Table 2. Vitamin $D$ and $E$ content of the liver of various mammals

\begin{tabular}{|c|c|c|c|c|}
\hline Animal & $\begin{array}{l}\text { Vitamin } D^{*} \\
(\mathrm{~m} \mu \mathrm{g} / \mathrm{g})\end{array}$ & References & $\begin{array}{l}\text { Vitamin } E \\
(\mu \mathrm{g} / \mathrm{g})\end{array}$ & References \\
\hline Rat & $\ldots$ & - & 4 & Swick \& Baumann (1952b) \\
\hline$O x$ & $2-2 I$ & Devaney \& Munsell (1935) & $10-14$ & $\begin{array}{l}\text { Quaife \& Dju (r949); Karrer, } \\
\text { Jaeger \& Keller (1940) }\end{array}$ \\
\hline Lamb & 5 & $\begin{array}{c}\text { Devaney \& Munsell (1935) } \\
\text { Bacharach (1946) }\end{array}$ & - & \\
\hline Pig & II & $\begin{array}{c}\text { Devaney \& Munsell (1935) } \\
\text { Bacharach (1946) }\end{array}$ & 4 & $\begin{array}{l}\text { Bratzler, Loosli, Krukovsky } \\
\text { Maynard (1950) }\end{array}$ \\
\hline Horse & - & - & I3 & Karrer et al. (1940) \\
\hline Rabbit & - & - & $3-5$ & Kofler (1945) \\
\hline Chick & 15 & - & 3 & Dam (r954) \\
\hline Birds & 50 & Shapiro (1942) & - & \\
\hline Fish & $1000-500,000$ & $\begin{array}{l}\text { Holmes, Tripp \& } \\
\text { Satterfield (i94I) }\end{array}$ & 18 & Lieck \& Willstaedt (1945) \\
\hline
\end{tabular}

$\mathrm{D}$ in tissues of the rat given a single massive dose of $\mathrm{I} \mathrm{mg}$ ergocalciferol $(40,000$ i.u.) (Cruickshank, Kodicek \& Armitage, I953).

We found in deficient rats that had no detectable vitamin $D$ in their livers a rise above the physiological level on the Ist day after dosing to about $36 \mu \mathrm{g}$, or 1500 i.u. From the Ist day to the 2 nd, the vitamin content decreased by about $25 \mu \mathrm{g}$ (I000 i.u.) to a level which was maintained for the rest of the period examined. This time curve is very similar to that found in vitamin A storage after a single dose (Booth, 1952). We do not know what happened to the vitamin lost from the liver. It could not be recovered elsewhere in the body and presumably was destroyed. The amounts found in the liver under these conditions represented about $4 \%$ of the dose. Another $2 \%$ was recovered elsewhere in the body, and thus only $6 \%$ appeared to have been absorbed, or at least stored. The small amounts absorbed $(6 \%)$ were in marked contrast to the great efficiency of utilization of vitamin A mentioned before $(80 \%)$. The small efficiency is of the same order as that found for tocopherol.

In more recent experiments (Cruickshank, Kodicek \& Armitage, I954), we investigated the effect of irradiation on the formation of vitamin $\mathrm{D}$ in the skin of deficient rats. We observed that irradiation with ultraviolet light caused a definite increase in the skin of the order of $20 \mathrm{i} . \mathrm{u} . / \mathrm{g}$. At the same time, a significant rise of vitamin $\mathrm{D}$ in the liver was found, indicating that the newly formed vitamin was being distributed throughout the body.

We have recently described a paper-chromatographic procedure for the estimation of vitamin D (Kodicek \& Ashby, r954) and 1 am able to supplement our balance experiments, previously done by biological assay, with new results obtained chemically. Graded doses of vitamin D $(0.25-8 \mathrm{mg})$ were given to groups of rachitic rats and the vitamin $D$ in their livers, kidneys and faeces was determined. There was a rise in the liver reserves directly proportional to the dose given until a dose of $4 \mathrm{mg}$ was reached. Then a relative decrease occurred comparable to that found with large doses of vitamin A. On the 2nd day after dosing, there was a significant 
drop in the liver stores, as observed previously, and the decrease was proportional to the amount present in the liver on the ist day. The decrease amounted to $40-50 \%$ of the total, but at the $8 \mathrm{mg}$ dose level it was only small (I $5 \%$ ). The fate of the vitamin $\mathrm{D}$ not recovered is at present unknown.

\section{Vitamin $E$}

Values for the liver content of vitamin $\mathrm{E}$ in various animals are given in Table 2.

Vitamin $E$ occurs in man mainly in the body fat which contains $65-75 \%$ of the total (Quaife \& Dju, 1949) and only a small portion is found in the liver (Table 3 ). The newborn has only a small reserve, though vitamin $\mathrm{E}$ appears to pass through the placenta. Prematures are reported to have higher tocopherol reserves (Mason, Dju \& Filer, 1952), a finding similar to that reported for vitamin A (cf. Moore, I $953 a$ ). With increasing age, the amount of vitamin $\mathrm{E}$ increases, chiefly in the body fat. In advanced age there is a sudden decrease in the vitamin $E$ content in liver, body fat and elsewhere (Mason et al. 1952) (Table 3).

\section{Table 3. Vitamin $E$ content of human livers and body fat}

(Abderhalden, 1945; Quaife \& Dju, 1949; Mason et al. 1952)

$\begin{array}{ccc}\text { Liver } & \text { Body fat } \\ (\mu \mathrm{g} / \mathrm{g}) & (\mu \mathrm{g} / \mathrm{g}) \\ \text { Foetus }(3-6 \text { months) } & 3-6 & - \\ \text { Infant: newborn } & 5 & \text { I I } \\ \text { premature } & \text { II } & 21 \\ \text { Child: } 3 \text { days }-3 \text { years } & 8 & 24 \\ \text { 1 3-17 years } & 13 & 93 \\ \text { Adult: various ages } & 25 & 350 \\ \text { 6r-93 years } & 9 & 99\end{array}$

Storage. Graded doses of the vitamin cause a proportional increase in the tissues (Bratzler, Loosli, Krukovsky \& Maynard, I950) but, in contrast to the distribution before dosing, the liver takes the main share of the ingested vitamin. Again the storage capacity exceeds the physiological level many hundred times. Quaife (1952) reports that about $10 \%$ of the dose is found in the liver of rats, but the stores do not seem to be maintained for long. Similar results have been obtained by Mason (I942) using a biological-assay procedure, by Hines \& Mattill (I943) and Criddle $\&$ Morgan (1947).

\section{Vitamin $K$}

The vitamin $\mathrm{K}$ content of the liver of the chick and pig is extremely small $(<\mathrm{I} \cdot 5 \mu \mathrm{g}$ and $8 \mu \mathrm{g} / \mathrm{g}$ dry matter, respectively), but the liver appears still to be richest in it of the tissues so far examined (Dam \& Schønheyder, 1936; Dam, Glavind, Lewis \& Tage-Hansen, 1938).

Storage. Dam (1954) recently found that intravenous injections of vitamin $\mathrm{K}_{1}$ cause a $1000-f o l d$ increase of vitamin $\mathrm{K}$ in the liver of chicks (to $1000 \mu \mathrm{g} / \mathrm{g}$ ). On the other hand, oral administration or injection of vitamin $\mathrm{K}$ substitutes had little or no effect. The latter finding is borne out by the similar experience of Solvonuk, 
Jaques, Leddy, Trevoy \& Spinks (1952) who injected ${ }^{14} \mathrm{C}$-labelled vitamin $\mathrm{K}$ substitute. These results thus indicate that the natural phyllo- or difarnesylhydroquinones are the substances necessary for the formation of blood-clotting factors, namely prothrombin and proconvertin, which are elaborated in the liver. A similar conclusion can be drawn from recent results of Dam \& Sendergaard (1953) who showed that vitamin $\mathrm{K}_{1}$ has a quicker effect than vitamin $\mathrm{K}$ substitutes, and also from the apparent inactivity of the latter compounds to alleviate the effects produced by dicoumarol.

\section{Ascorbic acid}

\section{Unclassified vitamins}

The vitamin C content of livers of various species ranges from ${ }_{5} 50$ to $400 \mu \mathrm{g} / \mathrm{g}$ (Giroud, 1938). The differences in the vitamin content between species are only slight, whether the animal can synthesize its own ascorbic acid or is dependent on an external supply.

Again dosing with a large amount of vitamin C (roo mg) causes only a temporary rise in the vitamin $\mathrm{C}$ content of liver (within the first $4 \mathrm{~h}$ ) which returns soon to a level found normally in the animal (Poumeau-Delille, I95 I).

\section{Vitamin $B_{12}$}

Table 4 shows the vitamin $B_{12}$ content of livers of some mammals. The low values in the pernicious-anaemia patients obtained by liver biopsy are worth noting (Drouet, Wolff \& Raubert, 195I). After therapy, the amount in the liver increases.

As would be expected, a greater increase is found when vitamin $B_{12}$ is injected than when given orally to rats (Lewis, Tappan \& Elvehjem, I952). The vitamin can

\section{Table 4. Vitamin $B_{12}$ content of the liver of various mammals}

\begin{tabular}{|c|c|c|c|}
\hline Animal & & $\begin{array}{l}\text { Content } \\
(\mathrm{m} \mu \mathrm{g} / \mathrm{g})\end{array}$ & References \\
\hline $\mathrm{Ox}$ & & $150-770$ & $\begin{array}{l}\text { Thompson, Dietrich \& Elvehjem (1950); } \\
\text { Lewis, Register, Thompson \& Elvehjem } \\
\text { (I949): Scheid \& Schweigert (I951) }\end{array}$ \\
\hline Chick & & I IO & $\begin{array}{l}\text { Scheid \& Schweigert (195I); Yacowitz, Hill, } \\
\text { Norris \& Heuser (1952) }\end{array}$ \\
\hline \multirow{2}{*}{ Man } & After $50 \mu \mathrm{g} / \mathrm{I} 00 \mathrm{~g}$ diet for 30 days & 480 & Yacowitz et al. (1952) \\
\hline & $\begin{array}{l}\text { Pernicious anaemia } \\
\text { After treatment }\end{array}$ & $\left.\begin{array}{l}23-140 \\
68-272\end{array}\right\}$ & Drouet et al (1951) \\
\hline
\end{tabular}

be found in the tissues of the cat within $2 \mathrm{~h}$ of injection (Smith, Gurney, Howat \& Chalmers, 1952). Actually there seems to be more in the kidney and spleen than in the liver.

In rats, deficient in vitamin $B_{12}$, the concentration drops to about $26 \mathrm{~m} \mu \mathrm{g} / \mathrm{g}$ and increasing doses raise the content proportionally up to the physiological level. There is no evidence so far that the liver can store more than this saturation level (Scheid, Andrews \& Schweigert, I95 I). Ford, Kon \& Porter (1952) found that in 
chicks $20 \%$ of the dose of $2 \mu \mathrm{g} / 100 \mathrm{~g}$ diet is recovered in the liver. Experiments with labelled cyanocobalamin conducted by Smith et al. (I952) and by Chow (I952) indicate that the labelled vitamin is fixed to a certain extent in the liver. Further doses of non-labelled vitamin do not seem to dislodge the label from the liver. Animals first given liberal doses of non-labelled vitamin, and then ${ }^{60} \mathrm{Co}-$ cyanocobalamin, incorporated much less of the labelled factor in their livers. This finding also would indicate that the liver has only a limited capacity to store this vitamin.

\section{Conclusion}

I would like to draw attention to the differences in storage in liver between those water-soluble vitamins that are incorporated into enzyme systems and which I have called prosthetins, and the fat-soluble vitamins. The former reach a saturation point which approximately equals that of their normal level, but the latter deposit in the liver in excess amounts. This and other differences may point to the fact that fat-soluble vitamins do not act in classical coenzyme systems.

I am grateful to Drs H. Dam, T. Moore, E. Lester Smith, J. W. G. Porter, L. D. Wright and others for supplying me with valuable information, in some instances not yet published.

\section{REFERENCES}

Abderhalden, R. (1945). Z. Vitaminforsch. 16, 309.

Arens, J. F. \& van Dorp, D. A. (1946). Nature, Lond., 157, I90.

Bacharach, A. L. (1946). In The Nation's Food, p. 240. [A. L. Bacharach \& T. Rendle, editors.] London: Society of Chemical Industry.

Baumann, C. A., Foster, E. G. \& Lavik, P. S. (194I). F. Nutr. 21, 43 I.

Baumann, C. A., Foster, E. G. \& Moore, P. R. (1942). F. biol. Chem. 142, 597.

Booth, V. H. (1952). F. Nutr. 48, I3.

Bratzler, J. W., Loosli, J. K., Krukovsky, V. N. \& Maynard, L. A. (1950). F. Nutr. 42, 59.

Braude, R., Henry, K. M., Kon, S. K. \& Thompson, S. Y. (1947). Brit. F. Nutr. 1, vi.

Burgess, R. C., Gluck, M., Brisson, G. \& Laughland, D. H. (r95I). Arch. Biochem. Biophys. 33, 339.

Chow, B. F. (1952). Recent Advances in Nutrition Research with Emphasis on the Newer B Vitamins. Nutrition Symposium Series, National Vitamin Foundation Inc. no. 5, p. I. New York: National Vitamin Foundation Inc.

Coates, M. E., Harrison, G. F., Kon, S. K., Porter, J. W. G. \& Thompson, S. Y. (I952). Chem. E Ind. p. I 49 .

Criddle, J. E. \& Morgan, A. F. (I947). Fed. Proc. 6, 247.

Cruickshank, E. M., Kodicek, E. \& Armitage, P. (1953). Biochem. F. 54, 337.

Cruickshank, E. M., Kodicek, E. \& Armitage, P. (1954). In preparation.

Dam, H. (1954). Private communication.

Dam, H., Glavind, J., Lewis, L. \& Tage-Hansen, E. (1938). Skand. Arch. Physiol. 79, 121.

Dam, H. \& Schønheyder, F. (1936). Biochem. f. 30, 897.

Dam, H. \& Søndergaard, E. (1953). Experientia, 9, 26.

Davies, A. W. \& Moore, T. (1934). Biochem. Y. 28, 288.

Davies, A. W. \& Moore, T. (I94I). Nature, Lond., 147, 794.

Davies, A. W. \& Moore, T. (1948). Biochem. F. 42, lxiii.

Devaney, G. M. \& Munsell, H. E. (1935). F. Home Econ. 27, 240.

Drouet, P. L., Wolff, R. \& Raubert, G. (1951). Bull. Soc. méd. Hôp. Paris, 67, 28 I.

Eaton, H. D., Spielman, A. A., Loosli, J. K., Thomas, J. W., Norton, C. L. \& Turk, K. L. (1947). F. Dairy Sci. 30, 787 .

Ford, J. E., Kon, S. K. \& Porter, J. W. G. (1952). Biochem F. 52, viii.

Ganguly, J. \& Deuel, H. J. Jr. (1953). Nature, Lond., 172, 120.

Ganguly, J., Mehl, J. W. \& Deuel, H. J. Jr. (1953a). F. Nutr. 50, 59.

Ganguly, J., Mehl, J. W. \& Deuel, H. J. Jr. (1953b). $\mathcal{F}$. Nutr. 50, 73.

Giroud, A. (1938). Ergebn. Vitam.- u. Hormonforsch. x, 68.

Glover, J., Goodwin, T. W. \& Morton, R. A. (1948). Biochem. F. 43, 109. 
Goodwin, T. W. (195I). Brit. F. Nutr. 5, 94.

Graham, W., van Dorp, D. A. \& Arens, J. F. (1949). Rec. Trav. chim. Pays-Bas, 68, 609

Gray, E. LeB. \& Cawley, J. D. (1942). F. Nutr. 23, 301 .

Gray, E. LeB, Hickman, K. C. D. \& Brown, E. F. (1940). J. Nutr. 19, 39.

Greaves, J. D. \& Schmidt, C. L. A. (1934a). Univ. Calif. Publ. Physiol. 8, 43.

Greaves, J. D. \& Schmidt, C. L. A. (1934b). Univ. Calif. Publ. Physiol. 8, 49.

Guerrant, N. B. (1949). \%. Nutr. 37, 37 .

Guggenheim, K. (1952). F. Nutr. 46, 14 I.

Harris, P. L., Ames, S. R. \& Brinkman, J. H. (1951). 7. Amer. chem. Soc. 73, I 252.

Hartsook, E. W., Batchelor, E. \& Johnson, B. C. (1953). Proc. Soc. exp. Biol., N.Y, 83, 43.

Heymann, W. (1937-8). F. biol. Chem. 122, 249.

Heymann, W. (1938). Amer. F. Dis. Child. 55, 913.

High, E. G. \& Day, H. G. (195I). F. Nutr. 43, 245.

High, E. G. \& Wilson, S. S. (1953). F. Nutr. 50, 203.

Hines, L. R. \& Mattill, H. A. (1943). F. biol. Chem. 149, 549.

Holmes, A. D., Tripp, F. \& Satterfield, G. H. (I94I). Industr. Engng Chem. (Industr.) 33, 944

Johnson, R. M. \& Baumann, C. A. (1948a). F. Nutr. 35, 703.

Johnson, R. M. \& Baumann, C. A. (1948b). F. biol. Chem. r75, 811.

Karrer, P., Jaeger, W. \& Keller, H. (1940). Helv. chim. acta, 23, 464.

Kemmerer, A. R., Fraps, G. S. \& DeMottier, J. (1947). Arch. Biochem. 12, 135.

Kodicek, E. \& Ashby, D. R. (1954). Biochem. F. 57, xiii.

Kofler, M. (1945). Helv. chim. acta, 28, 26.

Kowalewski, K. \& Henrotin, E. (1950). Acta gastro-enterol. belg. 13, 864.

Krause, R. F. \& Alberghini, C. (1950). Arch. Biochem. 25, 396.

Krause, R. F. \& Powell, L. T. (1953). Arch. Biochem. Biophys. 44, 57.

Krinsky, N. 1. \& Ganguly, J. (1953). F. biol. Chem. 202, 227.

Lardy, H. A. \& Peanasky, R. (1953). Physiol. Rev. 33, 560.

Lemley, J. M., Brown, R. A., Bird, O. D. \& Emmett, A. D. (1947). F. Nutr. 33, 53.

Lewis, U. J., Register, U. D., Thompson, H. T. \& Elvehejm, C. A. (1949). Proc. Soc. exp. Biol., N.Y., 72, 479 .

Lewis, U. J., Tappan, D. V. \& Elvehjem, C. A. (1952). 7. biol. Chem. 199, 5 I 7.

Lieck, H. \& Willstaedt, H. (1945). Suensk kem. Tidskr. 57, 134.

McGugan, W. A. \& Laughland, D. H. (1952). Arch. Biochem. Biophys. 35, 428.

Mason, K. E. (I942). F. Nutr, 23, 7I,

Mason, K. E., Dju, M. Y. \& Filer, L. J. Jr. (1952). Fed. Proc. rr, 449.

Meyer, K. A., Popper, H., Steigmann, F., Walters, W. H. \& Zevin, S. (1942). Proc. Soc. exp. Biol., N.Y., 49, 589 .

Moore, T. (1 940). Biochem. F. 34, 1321 .

Moore, T. (1953a). In Symposium on Nutrition, p. 28. [R. M. Herriott, editor.] Baltimore: The Johns Hopkins Press.

Moore, T. (1953b). Proc. Nutr. Soc. 12, 121.

Moore, T. (1953c). In Biochemistry and Physiology of Nutrition, Vol. I, p. 265 [G. H. Bourne \& G. W. Kidder, editors.] New York: Academic Press Inc.

Moore, T., Sharman, I. M. \& Ward, R. J. (195I). Biochem. F. 49, xxxix.

Nor-El-Din, G. (1944). Ұ. Egypt. med. Ass. 27, 25 I.

Novelli, G. D. (1953). Physiol. Rev. 33, 525.

Popper, H. (194r). Arch. Path. 3x, 670.

Popper, H., Steigmann, F. \& Dyniewicz, H. A. (1942). Proc. Soc. exp. Biol., N.Y., 50, 266.

Poumeau-Delille, G. (195I). C. R. Soc. Biol., Paris, 145, 792.

Quaife, M. L. (1952). Congr. int. Biochim. II. Paris. Résumés des Communications, p. 221.

Quaife, M. L. \& Dju, M. Y. (I949). F. biol. Chem. 180, 263.

Ralli, E. P., Papper, E., Paley, K. \& Bauman, E. (194I). Arch. intern. Med. 68, 102.

Reddi, K. K. \& Kodicek, E. (1953). Biochem. F. 53, 286.

Reed, L. J. (1953). Physiol. Rev. 33, 544.

Robeson, C. D. \& Baxter, J. G. (1947). F. Amer. chem. Soc. 69, г36.

Scheid, H. E., Andrews, M. M. \& Schweigert, B. S. (I95 I). Proc. Soc. exp. Biol., N.Y., 78, $55^{8}$.

Scheid, H. E. \& Schweigert, B. S. (I95I). F. biol. Chem. 193, 299.

Schultz, A. S., Light, R. F., Cracas, L. J. \& Atkin, L. (1939). F. Nutr. 17, 143.

Shapiro, H. A. (1942). Clin. Proc., Cape Town, x, 253. Quoted in Chem. Abstr. (1943) 37, 6086.

Sharman, I. M. (1949). Brit. F. Nutr. 3, viii.

Smith, E. L., Gurney, D. M., Howat, A. G. \& Chalmers, J. N. M. (1952). Congr. int. Biochim. II. Paris. Résumes des Communications, p. r9. 
Snell, E. E. (1953). Physiol. Rev. 33, 509.

Sobel, A. E., Sherman, M., Lichtblau, J., Snow, S. \& Kramer, B. (1948). F. Nutr. $35,225$.

Solvonuk, P. F., Jaques, L. B., Leddy, J. E., Trevoy, L. W. \& Spinks, J. W. T. (1952). Proc. Soc, exp. Biol., N.Y., 79, 597.

Swick, R. W. \& Baumann, C. A. (1952a). Arch. Biochem. Biophys. 36, r2o.

Swick, R. W. \& Baumann, C. A. (1952b). Analyt. Chem. 24, 758.

Thompson, H. T., Dietrich, L. S. \& Elvehjem, C. A. (1950). F. biol. Chem. 184, 75.

Totter, J. R., Martindale, W. E., McKee, M., Keith, C. K. \& Day, P. L. (I949). Proc. Soc. exp. Biol., N.Y., 70, 435 .

Wald, G. (I953). In Symposium on Nutrition, p. 73. [R. M. Herriott, editor.] Baltimore: The Johns Hopkins Press.

Wright, L. D. \& Skeggs, H. R. (1946). Proc. Soc. exp. Biol., N.Y., 63, 327.

Yacowitz, H., Hill, C. H., Norris, L. C. \& Heuser, G. F. (1952). Proc. Soc. exp. Biol., N.Y., 79, 279.

Zechmeister, L. (1937). Ergebn. Physiol. 39, 117.

\title{
Disorders of the Liver in Tropical Nutritional Diseases
}

\author{
By J. Waterlow, Department of Physiology, University College of the West Indies, \\ Jamaica, and Medical Research Council
}

It is now well recognized that liver disease is more common in the tropics than in temperate countries. I think it is reasonable to attribute this to malnutrition, but we cannot regard it as proven. In many instances the relation to diet is not clearcut, and the lesions and their sequence in man do not always resemble those that have been produced by dietary means in animals.

If we leave aside conditions that are undoubtedly caused by infection or infestation, the common types of liver damage may be classified broadly under three heads: fatty liver, fibrosis and cirrhosis, and carcinoma. Of these I shall only consider the first two. As far as I know, massive necrosis or acute atrophy is not more common in the tropics than elsewhere, and therefore I shall not discuss this either.

Fatty liver. This is the most clear-cut form of dietary liver injury in man. It is commonly found in infants and young children, and is a prominent feature of the clinical syndrome of kwashiorkor. The evidence that the fatty liver is caused by malnutrition may be summarized as follows:

It typically comes on after weaning, at a time when the diet is grossly deficient; it is accompanied by oedema, hypoproteinaemia, and often by signs of various vitamin deficiencies; there is no constant relation to any infection or parasitic infestation; lastly, it responds to treatment by dietary means alone.

Admittedly, there is nothing specific about a fatty liver per se. It may be found in infants dying of many diseases, notably gastro-enteritis and tuberculosis. What does seem to be specific about the fatty liver of kwashiorkor is its intensity. The fat content is often $40 \%$ of the wet weight, and may even rise to $50 \%$-as much as, or more than, that resulting from diets producing the most intense fatty liver in animals. 